Potensi Ekstrak dan Fraksi Buah KemLoko... (Citra Agustina Isnaning, dkk)

\title{
POTENSI EKSTRAK DAN FRAKSI BUAH KEMLOKO (Phyllanthus emblica L.) SEBAGAI SUMBER ANTIOKSIDAN
}

\author{
Meiny Suzery*, Citra Agustina Isnaning, , Bambang Cahyono \\ Laboratorium Kimia Organik, Jurusan Kimia Fakultas Sains dan Matematika, Universitas \\ Diponegoro, Jl.Prof. Soedarto SH, Kampus Tembalang, Semarang 50275 \\ * Corresponding Author: meiny_suzery@undip.ac.id
}

\begin{abstract}
ABSTRAK
Tanaman KemLoko (Phyllanthus emblica L.) merupakan tanaman yang sering digunakan oleh masyarakat sebagai bahan obat tradisional. Aktivitas biologis tanaman tersebut diduga disebabkan oleh keberadaan senyawa-senyawa kelompok fenolat, terutama golongan flavonoid. Riset mengenai analisis kandungan senyawa fenolat, flavonoid dan aktivitas antioksidan dari ekstrak beserta fraksi-fraksi dari buah kemLoko dari Kabupaten Kendal, Jawa Tengah, Indonesia, untuk pertama kalinya dilaporkan pada publikasi ini. Buah kemLoko kering dimaserasi dalam metanol, diikuti partisi dengan gradien pelarut sehingga diperoleh fraksi $n$-heksana, fraksi diklorometana, fraksi etil asetat dan fraksi air. Analisis fenolat total, flavonoid total dan aktivitas peredaman radikal DPPH dilakukan terhadap ekstrak atau fraksi yang menunjukan test positif fenolat dan flavonoid. Hasil penelitian menunjukkan bahwa fraksi $n$-heksana dan fraksi diklorometana negatif pada uji fenolat dan flavonoid. Kandungan fenolat total ekstrak metanol, fraksi etil asetat dan fraksi air berturut turut adalah 351, 436 dan $111 \mathrm{mg}$ ekuaivalen asam galat/g ekstrak atau fraksi, sedangkan flavonoid total berturut-turut 200, 216 dan $70 \mathrm{mg}$ ekuivalen quercetin/g ekstrak atau fraksi. Aktivitas antioksidan ketiga sampel uji tersebut memiliki $\mathrm{IC}_{50}$ berkisar 58,4 sampai 120,9 . Fraksi etil asetat merupakan sampel uji yang paling aktif sebagai antioksidan, selain memiliki kadar fenolat total dan flavonoid total tertinggi.
\end{abstract}

Kata kunci: kemLoko, Phyllantus emblica, fenolat total, flavonoid total, antioxidan

\section{THE POTENCY OF KEMLOKO (Phyllanthus emblica L.) FRUIT EXTRACT AND FRACTION AS AN ANTIOXIDANT}

\begin{abstract}
This present study was carried out to evaluated total phenolic, total flavonoid and antioxidant activity of methanolic extract of Indonesian Phyllanthus emblica L. fruit and their fractions. Methanolic extract was fractionated by gradient solvent and produced $n$ hexane, dichloromethane, ethyl acetate and water fractions. The $n$-hexane and dichoromethane fractions showed negative test on phenolic and flavonoid. The other fractions then were subjected to analyzation of total phenolic, total flavonoid and DPPH scavenging activity using uv-vis spectrophotometry. The total phenolics content of methanol extract, ethyl acetate, and water fraction were 351, 436 and $111 \mathrm{mg}$ gallic acid equivalent/ gram extract or fraction, whereas the total flavonoid are 200, 216 and $70 \mathrm{mg}$ of quercetin equivalent/ gram extract or fraction. Antioxidant activity of the samples are $\mathrm{IC}_{50}$ : $58.4-120.9$. The ethyl acetate fraction is the most active as antioxidant.
\end{abstract}

Keywords : antioxidant, phenolic, flavonoid, emblica fruit, Phyllantus emblica L. 


\section{PENDAHULUAN}

Antioksidan merupakan senyawa yang dapat menetralkan radikal bebas di dalam tubuh manusia. Enzim-enzim seperti superoksida dismutase (SOD), gluthatione dan katalase merupakan antioksidan alami yang terdapat pada tubuh manusia (Prakash, 2001). Pertumbuhan radikal bebas atau spesi reaktif yang melebihi kapasitas antioksidan di dalam tubuh akan meningkatkan resiko timbulnya berbagai penyakit regeneratif seperti kanker, jantung, katarak, penuaan dini dan lainlain. Oleh karena itu, selain mengandalkan antioksidan dari dalam tubuh, manusia juga membutuhkan antioksidan dari luar tubuh untuk mencapai keseimbangan. Sumber-sumber antioksidan dapat berasal dari bahan yang diperoleh dari laut (Hanani, dkk., 2005) dan tanaman yang tumbuh di darat (Ramamoorty dan Bono, 2007).

Salah satu contoh tanaman yang diduga memiliki aktivitas antioksidan cukup tinggi adalah kemLoko (Phyllanthus emblica L.). Tumbuhan ini merupakan bahan yang sering digunakan oleh masyarakat sebagai obat tradisional. Tanaman ini di India telah digunakan untuk mengobati penyakit kanker, diabetes, hati (liver), gangguan jantung dan anemia (Khan, 2009). Aktivitas biologis tersebut diduga disebabkan oleh adanya senyawa-senyawa bioaktif dari metabolit sekunder yang terkandung di dalamnya, khususnya senyawa dari golongan fenolat dan flavonoid.

Menurut penelitian yang telah dilakukan oleh Liu dkk. (2008), buah kemLoko mengandung senyawa-senyawa fenolat, seperti geraniin, quercetin 3- $\beta$-Dglukopiranosida, kaempferol 3- $\beta$-Dglukosapiranosida, isokorilagin, quercetin, dan kaempferol. Selain itu, tanaman ini juga mengandung senyawa asam galat, asam ellagat, 1-O-galloylbeta-D-glukosa, asam-3-etilgalat dan corilagin (Zhang dkk., 2003). Senyawa apeganin dan asam askorbat juga pernah ditemukan dalam tanaman kemLoko (ElDesouky dkk., 2008; Khurdiya dan Jain, 2004). Gugus hidroksil yang bersifat asam pada senyawa-senyawa fenolat tersebut diduga sangat berperan dalam reaksi oksidasi-reduksi yang terjadi di dalam tubuh (Huang, 2005).

Penelitian yang berhubungan dengan analisis kandungan senyawa fenolat, flavonoid dan aktivitas antioksidan dari buah kemLoko yang berasal dari berbagai daerah di Cina dengan lingkungan geografis yang berbeda pernah dilakukan (Liu, dkk., 2008). Penelitian dengan lingkup yang sama, dengan sampel yang berasal dari daerah tropis seperti Indonesia, khususnya dari Kabupaten Kendal, penting dilakukan untuk melihat dan membandingkan kualitas bahan tersebut dengan komoditas dari daerah lain. Selain itu, fraksinasi terhadap ekstrak metanol buah kemLoko juga perlu dipaparkan guna melihat perbandingan harga indikator-indikator yang terlibat dalam peredaman radikal bebas tersebut pada ekstrak dan fraksi-fraksinya.

Secara garis besar, penelitian dibagi menjadi empat tahapan, yaitu perolehan total ekstrak metanol yang kemudian diikuti dengan fraksinasi dengan metode gradien pelarut, analisis fenolat total dan flavonoid total, dan diakhiri dengan analisis aktivitas antioksidan untuk ekstrak dan fraksifraksi yang menunjukkan test positif terhadap fenolat.

\section{METODOLOGI}

\section{Alat dan Bahan}

Alat-alat yang digunakan: Rotary evaporator Buchi Switzerland, spektrofotometer UV-Vis U-2800 Hitachi. Bahan yang digunakan: sampel buah kemLoko kering yang diambil dari 
Petani Pengepul di Kecamatan Boja Kabupaten Kendal, Asam galat, quercetin, buthyl hidroksitoluena (BHT), reagen Folin-Ciocalteu, 1,1-difenil-2pikrilhidrazil (DPPH), semua pelarut memiliki kualitas pro analisis (pa), kecuali disebutkan lain

\section{PROSEDUR KERJA}

\section{Penentuan Kadar Air Simplisia.}

Penentuan kadar air dilakukan dengan pemanasan oven, sesuai dengan SNI 01-2891-1992 butir 5.1.

\section{Penyiapan Sampel.}

Sampel buah kemLoko kering (200 gram) dimaserasi dalam $500 \mathrm{~mL}$ metanol selama 24 jam. Filtrat metanol kemudian dipisahkan dari ampasnya. Ekstraksi diulang enam kali dengan jumLah pelarut yang sama. Larutan metanol yang diperoleh kemudian dipekatkan dengan rotary evaporator, untuk mendapatkan ekstrak kasar (selanjutnya disebut $\mathbf{E}_{\mathbf{m e t}}$ ). Crude coklat yang diperoleh ditimbang, dan kemudian dilarutkan dalam $100 \mathrm{~mL}$ aquades. Larutan air ini kemudian dipartisi dengan corong pisah berturut-turut dengan pelarut $3 \mathrm{x} 100 \mathrm{~mL} n$-heksan, diklorometan dan etil asetat. Larutanlarutan hasil partisi ini akhirnya disaring dan dipekatkan sehingga menghasilkan fraksi $n$-heksan, diklorometan, etil asetat dan air, yang selanjutnya disebut sebagai $\mathbf{F}_{\text {hek }}, \mathbf{F}_{\text {dcm }}, \mathbf{F}_{\text {ea }}$ dan $\mathbf{F}_{\text {air }}$.

\section{Analisis Kualitatif Senyawa Fenolat dan Flavonoid.}

\section{Preparasi sampel untuk uji.}

Masing-masing ekstrak atau fraksi $(0,1$ gram $)$ ditambahkan pelarut campuran kloroform/aquades (1/1). Campuran dikocok dalam tabung reaksi dan dibiarkan sejenak hingga terbentuk dua lapisan. Lapisan air yang berada di atas digunakan untuk pemeriksaan flavonoid dan fenolat.

\section{Pemeriksaan senyawa fenolat.}

Lapisan air dimasukkan ke dalam plat tetes dan ditambahkan pereaksi $\mathrm{AlCl}_{3}$. Reaksi positif ditandai dengan terbentuknya warna biru/ungu.

\section{Pemeriksaan senyawa flavonoid}

Lapisan air diambil sedikit kemudian dimasukkan ke dalam tabung reaksi dan ditambahkan sedikit bubuk logam $\mathrm{Mg}$ serta beberapa tetes asam klorida $(\mathrm{HCl})$ pekat. Reaksi positif ditandai dengan terbentuknya warna oranye.

\section{Analisis Kuantitatif Senyawa Fenolat Total}

\section{Pembuatan kurva kalibrasi asam galat dengan reagen Folin-Ciocalteu}

Dibuat larutan asam galat (dalam metanol) dengan konsentrasi 400, 500, 600, dan $700 \mathrm{mg} / \mathrm{L}$. Masing-masing konsentrasi tersebut, dipipet $0,2 \mathrm{~mL}$ dan ditambahkan 15,8 mL aquades serta $1 \mathrm{~mL}$ reagen Folin-Ciocalteu. Larutan bening kekuningan dikocok hingga homogen, kemudian didiamkan selama 8 menit, lalu ditambahkan $3 \mathrm{~mL}$ larutan $\mathrm{Na}_{2} \mathrm{CO}_{3} 20 \%$. Campuran dikocok hingga homogen. Larutan kembali didiamkan selama 30 menit pada suhu kamar hingga terbentuk warna biru. Serapan larutan diukur dengan spektrofotometer UV-Vis pada panjang gelombang $765 \mathrm{~nm}$, lalu dibuat kurva kalibrasinya hubungan antara konsentrasi asam galat (mg/L) dengan absorbansi (Waterhouse, 1999).

\section{Penentuan kandungan fenolat total dengan metode Folin-Ciocalteu}

Dari hasil analisis kualitatif fenolat dan flavonoid telah diperoleh 
hasil bahwa hanya $\mathbf{E}_{\text {met }}, \mathbf{F}_{\text {ea }}$ dan $\mathbf{F}_{\text {air }}$ menunjukkan test positif sehingga analisis selanjutnya hanya dilakukan terhadap ekstrak dan fraksi ini. Masingmasing ekstrak atau fraksi ( $\mathbf{E}_{\text {met }}, \mathbf{F}_{\text {ea }}$ dan $\left.\mathbf{F}_{\text {air }}\right)$ ditimbang sebanyak 0,3 gram kemudian dilarutkan sampai $10 \mathrm{~mL}$ dengan metanol. Dipipet 0,2 $\mathrm{mL}$ larutan kemudian ditambahkan $15,8 \mathrm{~mL}$ aquades dan $1 \mathrm{~mL}$ reagen Folin-Ciocalteu lalu dikocok hingga homogen. Setelah homogen akan terbentuk larutan berwarna bening kekuningan. Larutan didiamkan selama 8 menit, selanjutnya ditambahkan 3 mL larutan $\mathrm{Na}_{2} \mathrm{CO}_{3} 20 \%$ lalu dikocok hingga homogen. Larutan kembali didiamkan selama 30 menit pada suhu kamar hingga terbentuk warna biru. Serapan larutan diukur dengan spektrofotometer UV-Vis pada panjang gelombang $765 \quad \mathrm{~nm}$ (dilakukan pengenceran seperlunya agar masuk dalam kurva kalibrasi). Kadar fenolat total yang diperoleh merupakan mg ekuivalen asam galat/gram sampel (Orak, 2006).

\section{Analisis Kuantitatif Flavonoid Total.}

\section{Pembuatan kurva kalibrasi quersetin}

Kurva standar quersetin dilakukan dengan cara membuat larutan (dalam metanol) dengan konsentrasi 700, 800, 900, 1000, dan 1100 mg/L. Sebanyak 0,5 $\mathrm{mL}$ larutan dari berbagai konsentrasi direaksikan dengan $2 \mathrm{~mL}$ akuades dan $0,15 \mathrm{~mL} \mathrm{NaNO}_{2} 5 \%$ kemudian didiamkan selama 6 menit. Sebanyak $0,15 \mathrm{~mL} \mathrm{AlCl}_{3}$ $10 \%$ ditambahkan ke dalam larutan, kemudian didiamkan kembali selama 6 menit. Larutan direaksikan dengan $2 \mathrm{~mL}$ $\mathrm{NaOH} 4 \%$, kemudian diencerkan hingga volume total mencapai $5 \mathrm{~mL}$ dan didiamkan selama 15 menit. Pada akhirnya, absorbansi dari larutan standar diukur pada panjang gelombang $510 \mathrm{~nm}$ menggunakan spektrofotometer UV-Vis. Kurva standar diperoleh dari hubungan antara konsentrasi quersetin (mg/L) dengan absorbansi.

\section{Analisis flavonoid total}

Kandungan flavonoid total ditentukan berdasarkan metode kerja Zou dkk. (2004). Masing-masing ekstrak atau fraksi $\left(\mathbf{E}_{\text {met }}, \mathbf{F}_{\text {ea }}\right.$ dan $\left.\mathbf{F}_{\text {air }}\right)$ ditimbang sebanyak 0,3 gram kemudian dilarutkan sampai $10 \mathrm{~mL}$ dengan metanol. Sebanyak 0,5 mL larutan ekstrak dicampurkan dengan $2 \mathrm{~mL}$ aquades dan $0,15 \mathrm{~mL}$ $\mathrm{NaNO}_{2} 5 \%$. Setelah didiamkan selama 6 menit, larutan ditambahkan dengan 0,15 $\mathrm{mL} \mathrm{AlCl}_{3} 10 \%$ dan didiamkan kembali selama 6 menit. Larutan ditambah $2 \mathrm{~mL}$ $\mathrm{NaOH} 4 \%$ dan diencerkan hingga $5 \mathrm{~mL}$. Campuran digojog kemudian didiamkan selama 15 menit. Larutan selanjutnya diukur serapannya menggunakan spektrofotometer UV-Vis pada panjang gelombang $510 \quad \mathrm{~nm}$ (dilakukan pengenceran seperlunya agar masuk dalam kurva kalibrasi). Kadar flavonoid yang diperoleh merupakan mg ekuivalen quercetin/gram sampel.

\section{Penentuan Aktivitas Antioksidan dengan Metode DPPH}

\section{Penentuan panjang gelombang serapan maksimum DPPH}

Dibuat larutan DPPH $50 \mu \mathrm{M}$ dengan melarutkan 1,97 mg serbuk DPPH ke dalam $100 \mathrm{~mL}$ metanol, terbentuk larutan berwarna ungu tua. Dipipet sebanyak 3,8 mL larutan tersebut dan dimasukkan ke dalam botol vial 15 $\mathrm{mL}$ dan ditambahkan dengan $0,2 \mathrm{~mL}$ metanol. Larutan dikocok hingga homogen dan dibiarkan selama 30 menit di tempat gelap. Serapan larutan diukur dengan spektrofotometer UV-Vis pada panjang gelombang 400-600 nm. Absorbansi maksimum yang ditujukkan pada panjang gelombang $515 \mathrm{~nm}$ merupakan absorbansi kontrol $\left(\mathrm{A}_{0}\right)$ 
DPPH. Digunakan metanol sebagai blanko (Molineux, 2004).

\section{Pemeriksaan aktivitas antioksidan}

Masing-masing sampel (ekstrak atau fraksi) dibuat konsentrasi $(10,30$, 50, 70, $90 \mu \mathrm{g} / \mathrm{mL}$ ) dalam metanol. Masing-masing sampel dipipet sebanyak $0,2 \mathrm{~mL}$ dan dimasukkan ke dalam vial yang kemudian ditambahkan 3,8 mL larutan $\mathrm{DPPH} \quad 50 \mu \mathrm{M}$. Campuran dihomogenkan dan dibiarkan selama 30 menit. Serapan diukur dengan spektrofotometer UV-Vis pada panjang gelombang 515 nm (Molyneux, 2004). Quercetin dan BHT diperlakuan sama dengan sampel sebagai kontrol positif. Kemampuan untuk meredam radikal DPPH (inhibisi) dihitung menggunakan persamaan :

$$
\% \text { Inhibisi }=\frac{A_{0}-A_{s}}{A_{0}} \times 100 \%
$$

Perhitungan $\mathrm{IC}_{50}$ diperoleh dari perpotongan garis antara $50 \%$ daya inhibisi dengan konsentrasi sampel (Utami dkk., 2006).

Secara garis besar, penelitian yang dilakukan diperlihatkan pada Gambar 1.

\section{HASIL DAN PEMBAHASAN}

$$
\text { Penelitian kimia yang }
$$

berhubungan dengan antioksidan pada umumnya diimplementasikan melalui tahap-tahap analisis fenolat total, flavonoid total dan aktivitas antioksidan melalui analisis DPPH. Parameterparameter tersebut pada umumnya dikompilasi dengan data-data hasil uji dari daerah lain atau tumbuhan lain sehingga dapat digunakan untuk memberikan gambaran mengenai kualitas bahan alam atas dasar molekul yang dikandungnya. Data-data yang diperoleh dari penelitian ini dapat pula digunakan sebagai dasar dalam formulasi untuk kepentingan uji praklinis terhadap dosis yang akan diterapkan.

KemLoko (Phyllanthus emblica L.), yang merupakan tanaman dari suku Euphorbiciae, dipilih sebagai obyek penelitian, mengingat tanaman ini, secara kemotaksonomi, mengandung senyawasenyawa bioaktif yang bersifat sebagai antioksidan. Buah tanaman dikumpulkan dari petani di Kecamatan Boja, Kabupaten Kendal, yakni daerah yang

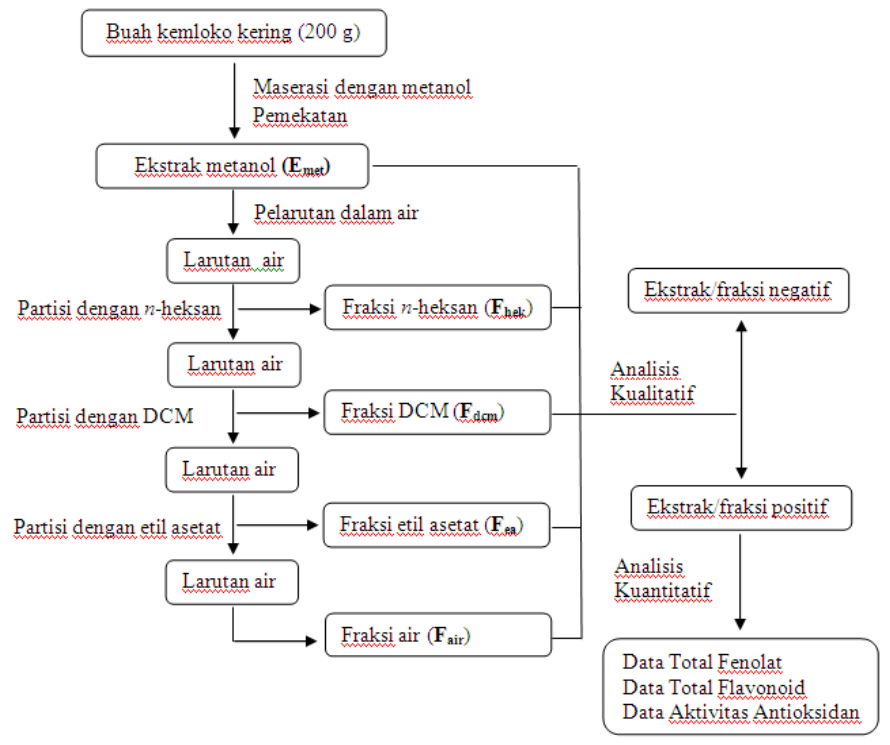

Gambar 1. Alur kerja penelitian 
merupakan pusat penghasil buah kemLoko di Jawa Tengah. Dari hasil wawancara dengan petani di daerah tersebut, diketahui bahwa Kecamatan Boja dapat menghasilkan buah kemLoko sebanyak 24 ton per tahun dan pada umumnya diambil pengepul untuk dijual kepada perusahaan kosmetika.

Buah kemLoko kering yang dikumpulkan dari petani pengepul daerah Boja memiliki kadar air 10,82\% (b/b), dapat diterima untuk perdagangan sesuai Standar Nasional Indonesia untuk Rempah-rempah Bubuk (SNI 01-37091995, maksimal 12\%). Ekstrak total buah kemLoko dapat diperoleh secara mudah melalui maserasi berulang dengan menggunakan pelarut metanol. Evaporasi vakum terhadap ekstrak ini telah menghasilkan crude berwarna coklat sebanyak 38,5\% dari berat simplisia. Liu dkk (2008), yang telah membandingkan rendemen dari tujuh daerah yang berbeda telah melaporkan bahwa total ekstrak metanolat dari daratan Cina berkisar antara 21-39\% .

Tabel 1. Rendemen ekstrak dan fraksi kemLoko

\begin{tabular}{lc}
\hline $\begin{array}{l}\text { Jenis } \\
\text { ekstrak/fraksi }\end{array}$ & Rendemen $(\boldsymbol{\%})$ \\
\hline $\mathbf{E}_{\text {Met }}$ & 38,5 \\
$\mathbf{F}_{\text {hek }}$ & 1,2 \\
$\mathbf{F}_{\text {dcm }}$ & 2,4 \\
$\mathbf{F}_{\text {ea }}$ & 15,6 \\
$\mathbf{F}_{\text {air }}$ & 19,3 \\
\hline
\end{tabular}

Tabel 2: Hasil uji kualitatif senyawa fenolat dan flavonoid

\begin{tabular}{lcc}
\hline $\begin{array}{c}\text { Jenis } \\
\text { ekstrak/fraksi }\end{array}$ & $\begin{array}{c}\text { Hasil uji } \\
\text { fenolat }\end{array}$ & $\begin{array}{c}\text { Hasil uji } \\
\text { flavonoid }\end{array}$ \\
\hline $\mathbf{E}_{\text {Met }}$ & + & + \\
$\mathbf{F}_{\text {hek }}$ & - & - \\
$\mathbf{F}_{\text {dcm }}$ & - & - \\
$\mathbf{F}_{\text {ea }}$ & + & + \\
$\mathbf{F}_{\text {air }}$ & + & + \\
\hline
\end{tabular}


Hasil uji kualitatif ekstrak buah kemLoko tersebut menunjukkan bahwa senyawa-senyawa fenolat dan flavonoid hanya positif terjadi pada bagian yang bersifat semipolar sampai polar. Dilihat dari struktur fenolat dan flavonoid yang terkandung dalam buah kemLoko, pada umumnya memiliki gugusan yang dapat menyebabkan senyawa organik bersifat polar. Oleh karena itu, analisis selanjutnya akan lebih difokuskan terhadap ekstrak metanol, fraksi etil asetat dan fraksi air.

\section{Analisis Kuantiatif Senyawa Fenolat Total}

\section{Kurva kalibrasi asam galat}

Telah dibuat kurva kalibrasi asam galat sebagai pembanding ekivalen senyawa fenolat total yang terdapat pada sampel buah kemLoko. Pembuatan kurva kalibrasi ini (Gambar 2) berguna untuk membantu menentukan kadar senyawa fenolat dalam sampel buah kemLoko melalui persamaan regresi yang didapatkan.

Dari analisis terhadap larutan asam galat didapatkan kurva kalibrasi dengan persamaan regresi $\mathrm{Y}=0,001 \mathrm{x}+$
0,016 dan harga koefisien korelasi $\left(\mathrm{R}^{2}\right)$ yaitu 0,992 . Persamaan regresi menyatakan hubungan matematis antara konsentrasi asam galat dan absorbansinya pada pengukuran menggunakan spektrofotometer UV-Vis. Sedangkan harga koefisien korelasi $\left(\mathrm{R}^{2}\right)$ menyatakan keeratan hubungan/korelasi antara konsentrasi (sumbu x) dan absorbansi (sumbu y). Harga $\mathrm{R}^{2}$ yang mendekati angka 1 menyatakan bahwa persamaan regresi tersebut adalah linier dan konsentrasi mempengaruhi absorbansi sebesar 99\% (Andayani dkk., 2008 dan Rohman dkk., 2005).

\section{Penentuan kandungan senyawa fenolat total}

Senyawa-senyawa fenolat telah terbukti banyak memberikan kontribusi terhadap aktivitas antioksidan suatu sampel tanaman Liu dkk. (2008). Total kandungan senyawa fenolat pada masingmasing fraksi ditentukan berdasarkan persamaan regresi yang didapatkan pada kurva kalibrasi asam galat. Hasil analisis total kandungan senyawa fenolat ditunjukkan sebagai mg ekivalen asam galat/gram sampel kering (Tabel 3).

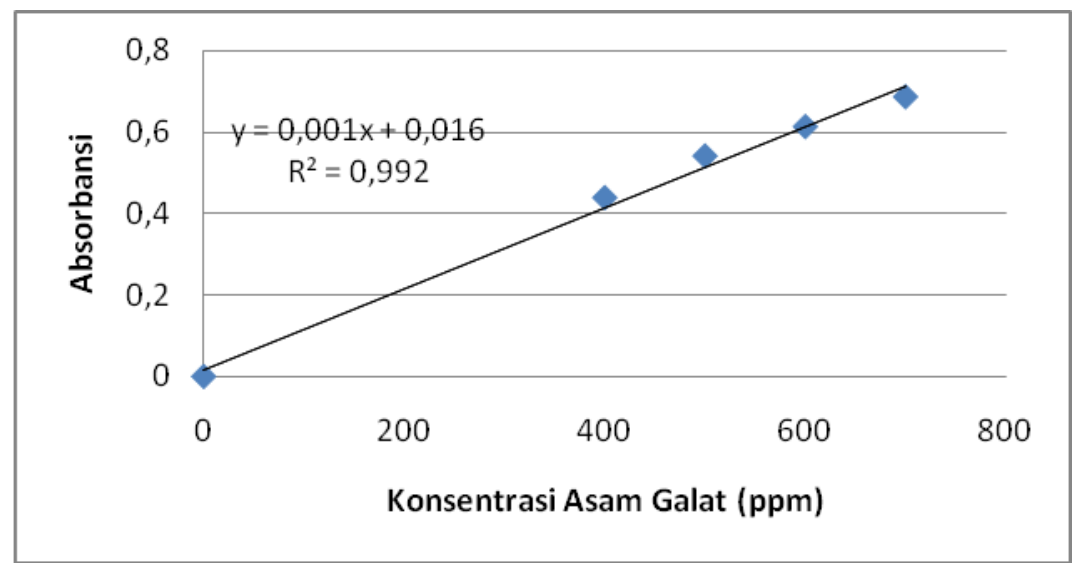

Gambar 2. Kurva kalibrasi asam galat dengan reagen Folin-Ciocalteu 
Tabel 3: Hasil penentuan kadar fenolat total buah kemLoko

\begin{tabular}{lcc}
\hline Sampel & $\begin{array}{c}\text { Kadar Fenolat Total (mg } \\
\text { ekivalen asam galat/gram } \\
\text { ekstrak atau fraksi) }\end{array}$ & $\begin{array}{c}\text { Kadar Fenolat Total (mg } \\
\text { ekivalen asam galat/gram } \\
\text { simplisia kering)* }\end{array}$ \\
\hline $\mathbf{E}_{\text {Met }}$ & 351 & 135 \\
$\mathbf{F}_{\mathbf{E A}}$ & 436 & 68 \\
$\mathbf{F}_{\text {air }}$ & 111 & 21 \\
\hline
\end{tabular}

* Hasil konversi dari kadat fenolat total dalam ekstrak dikalikan dengan rendement yang diperoleh pada table 1

Fraksi etil asetat merupakan bagian yang memiliki fenolat total terbesar dibanding dengan sampel uji yang lainnya. Walaupun demikian, bila ditinjau dari proses fraksinasi, tahap pemurnian seperti ini tidak efektif karena nilai fenolat total per gram simplisia kering asal hanya hampir sepertiga dari kadar fenolat total dari ekstrak metanol. Selanjutnya, dalam penelitian yang dilakukan Liu dkk. (2008) telah diketahui bahwa ekstrak metanol buah kemLoko Huizhou, Prov. Guangdong, memiliki total kandungan senyawa fenolat terbesar di daerah Cina, yaitu sebesar 439,9 mg asam galat/gram sempel kering. Perbedaan lingkungan, baik dari kandungan unsur hara dalam tanah maupun iklim diduga mempengaruhi kandungan golongan senyawa tersebut.

Perlu dicatat bahwa total kandungan senyawa fenolat $\mathbf{F}_{\mathbf{d c m}}$ dan $\mathbf{F}_{\text {hek }}$ tidak dilanjutkan karena kedua fraksi tersebut tidak dapat bercampurnya sampel uji dengan aquades pada saat pengujian dengan metode Folin-Ciocalteu sehingga hasil pembacaan absorbansi tidak dapat dipertanggungjawabkan

\section{Analisis Kuantiatif Senyawa Flavonoid Total \\ Kurva kalibrasi guercetin}

Quercetin digunakan sebagai standar dalam penentuan flavonoid total karena telah dilaporkan dapat ditemukan dalam tanaman kemLoko. Kurva kalibrasi quercetin dengan persamaan $\mathrm{y}=$ $0.0003 x+0,0007$ (Gambar 3). Kurva ini telah berhasil membantu untuk menentukan kadar senyawa flavonoid dalam sampel buah kemLoko didasarkan pada persamaan garis yang didapatkan.

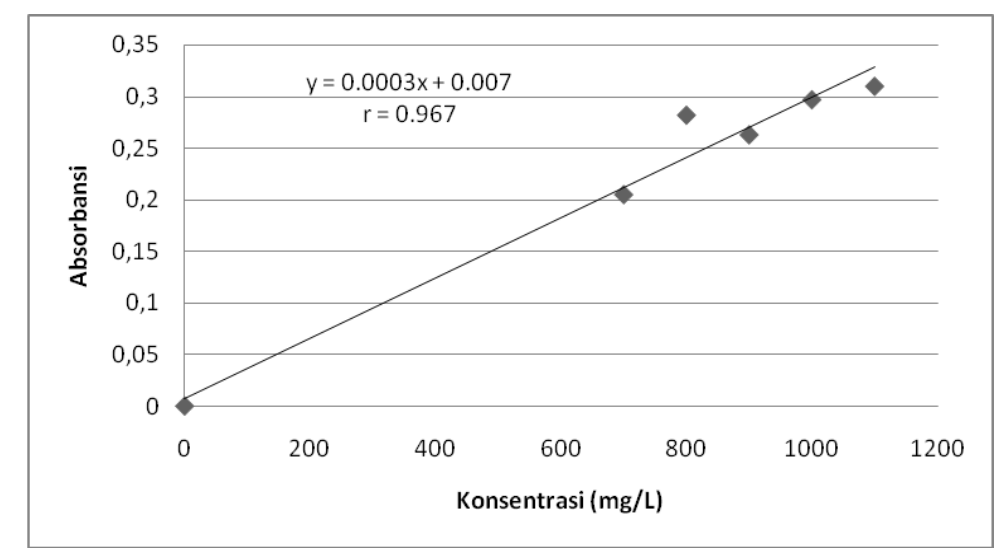

Gambar 3. Kurva kalibrasi quersetin dengan reagen $\mathrm{NaNO}_{2}, \mathrm{AlCl}_{3}$ dan $\mathrm{NaOH}$ 


\section{Penentuan kandungan senyawa flavonoid Total}

Aktivitas antioksidan buah
kemLoko diduga disebabkan oleh
keberadaan senyawa-senyawa flavonoid
di dalamnya. Hal ini dapat dibuktikan
dengan pemeriksaan flavonoid total pada
buah kemLoko. Total kandungan
senyawa flavonoid pada masing-masing
fraksi ditentukan berdasarkan persamaan
regresi yang didapatkan pada kurva
kalibrasi quercetin. Hasil analisis total
kandungan senyawa flavonoid
ditunjukkan sebagai mg ekivalen
quercetin/gram sampel kering.

Dari Tabel 4 dapat pula diprediksi bahwa fraksinasi terhadap ekstrak metanol tidak efektif mengingat kenaikan kadar flavonoid dalam fraksi etil asetat dengan kadar flavonoid dalam ekstrak metanol tidak sepadan dengan penurunan kadar flavonoid dalam sampel simplisia asal. Perlu dicatat bahwa kadar flavonoid total dalam simplisia kering sampel Indonesia ini hampir dua kali yang tumbuh di Cina berkisar 20,3 sd 38,7 mg ekivalen kuercetin/gram sampel kering (Liu, dkk, 2008).

\section{Penentuan aktivitas antioksidan}

DPPH (1,1-difenil-2pikrilhidrasil) merupakan radikal bebas yang stabil pada suhu kamar dan sering digunakan mengevaluasi aktivitas antioksidan beberapa senyawa atau ekstrak bahan alam (Gurav dkk., 2007). Warna larutan DPPH dalam metanol adalah ungu tua, warna ini dapat berkurang kepekatannya atau berubah menjadi kuning pucat apabila larutan bereaksi dengan senyawa lain yang dapat mendonorkan proton. Penambahan proton pada struktur radikal DPPH akan menyebabkan terjadinya reduksi membentuk DPPH non radikal. Berkurangnya intensitas warna tersebut ditandai dengan menurunnya absorbansi sperktrofotometer pada panjang gelombang $515 \mathrm{~nm}$ (Molyneux, 2004).

Tabel 4: Flavonoid total dalam ekstrak dan fraksi buah kemLoko

\begin{tabular}{lll}
\hline Sampel & $\begin{array}{l}\text { Kadar Flavonoid Total (mg } \\
\text { ekivalen kuercetin/gram } \\
\text { ekstrak/fraksi) }\end{array}$ & $\begin{array}{l}\text { Kadar Flavonoid Total (mg } \\
\text { ekivalen quersetin/gram } \\
\text { sampel )* }\end{array}$ \\
\hline $\mathbf{E}_{\text {Met }}$ & 200 & 76 \\
$\mathbf{F}_{\mathbf{E A}}$ & 216 & 34 \\
$\mathbf{F}_{\text {air }}$ & 70 & 14 \\
\hline
\end{tabular}

* Hasil konversi dari kadat flavonoid total dalam ekstrak dikalikan dengan rendement yang diperoleh pada table 1

Tabel 5: Aktivitas Antioksidan Ekstrak dan fraksi Buah KemLoko, BHT dan quersetin

\begin{tabular}{ll}
\hline Sampel & Nilai $\mathbf{I C}_{\mathbf{5 0}}(\mathbf{m g} / \mathbf{L})$ \\
\hline $\mathrm{E}_{\text {Met }}$ & 120,90 \\
$\mathrm{~F}_{\mathrm{EA}}$ & 56,45 \\
$\mathrm{~F}_{\text {air }}$ & 98,09 \\
BHT & 37,09 \\
Quersetin & 24,94 \\
\hline
\end{tabular}


Aktivitas antioksidan merupakan kemampuan suatau senyawa atau ekstrak untuk menghambat reaksi oksidasi yang dapat dinyatakan dengan persentase penghambatan atau persensentase inhibisi. Parameter yang digunakan untuk menunjukkan aktivitas antioksidan adalah harga konsentrasi efisien atau Efficient Concertation $\left(\mathrm{EC}_{50}\right)$ atau Inhibition Concertation $\left(\mathrm{IC}_{50}\right)$ yaitu konsentrasi suatu zat antioksidan yang menyebabkan 50\% DPPH kehilangan karakter radikal atau konsentrasi suatu zat antioksidan yang menberikan persentase pengahambatan sebesar $50 \%$. Zat yang mempunyai aktivitas antioksidan tinggi memiliki harga $\mathrm{EC}_{50}$ atau $\mathrm{IC}_{50}$ yang rendah.

Hasil uji aktivitas antioksidan dengan metode DPPH menunjukkan hasil bahwa ekstrak etil asetat mempunyai aktivitas antioksidan yang paling tinggi. Hal ini sesuai dengan penelitian yang dilakukan Liu dkk. (2008) terhadap sampel buah kemLoko dari Cina. Aktivitas peredaman radikal bebas DPPH ekstrak buah kemLoko diduga ditentukan oleh senyawa antioksidan yang terdapat di dalamnya yaitu vitamin $\mathrm{C}$ (Khurdiya dan Jain, 2004) serta senyawa fenolat seperti quercetin, asam galat dan kaempferol (Lui dkk., 2007). Mayoritas senyawa-senyawa tersebut bersifat semipolar. Walaupun demikian, seperti pada ekstrak tanaman Phyllanthus emblica atau ekstrak tanaman lain, secara keseluruhan aktivitas peredaman radikal bebas DPPH ekstrak buah kemLoko masih di bawah aktivitas antioksidan sintesis BHT dan quercetin.

Fraksi etil asetat yang merupakan sampel uji paling aktif dalam meredam radikal bebas memiliki harga fenolat total dan flavonoid total yang lebih rendah dari pada sampel uji ekstrak metanol. Hal ini dapat mengindikasikan bahwa senyawasenyawa asam karboksilat, baik bebas maupun terikat dengan fenolat, lebih berperan dalam memberikan kontribusi peredaman radikal.

\section{SIMPULAN}

Hasil analisis $\begin{array}{r}\text { screening } \\ \text { phytochemistry terhadap fenolat dan }\end{array}$
flavonoid menunjukkan hanya ekstrak
metanol, fraksi etil asetat dan fraksi air
yang menunjukkan test positif. Analisis
total fenolat dan total flavonoid terhadap
ketiga sampel uji tersebut menunjukkan
bahwa fraksi etil asetat merupakan
sampel uji yang paling aktif dalam
meredam radikal bebas dan memiliki
fenolat total serta flavonoid total
tertinggi.

\section{UCAPAN TERIMAKASIH}

\begin{tabular}{lr}
\multicolumn{3}{c}{ Penelitian ini dibiayai oleh DIPA } \\
Fakultas Matematika dan Ilmu \\
Pengetahuan alam & Universitas \\
Diponegoro Tahun 2013.
\end{tabular}

\section{DAFTAR PUSTAKA}

Andayani, R., Lisawati, Y., \& Maimunah, 2008, Penentuan Aktivitas Antioksidan, Kadar Fenolat Total dan Likopen pada Buah Tomat, Jurnal Sains dan Teknologi Farmasi, 13, 1-9.

El-Desouky, S.K., Ryu, S.Y., \& Kim, Y.K., 2008, A New Citotoxic Acylated Apigenin Glucoside from Phyllanthus emblica L., Nat. Prod. Res., 22, 91-95.

Gurav, S., Deshnkar, N., Gulkari, V., Duragkar, N., \& Patil, A., 2007, Free Radical Scavenging Activity of Polygala chinensis Linn, PharmacologyomLine, 2, 245253.

Hanani, E., Mun'im, A., \& Sekarini, R., 2005, Identifikasi Senyawa Antioksidan dalam Spons Callyspongia sp. dari Kepulauan 
Potensi Ekstrak dan Fraksi Buah KemLoko... (Citra Agustina Isnaning, dkk)

Seribu, Majalah Ilmu Kefarmasian, 2, 127-133.

Huang, D., Ou, B., \& Prior, R.L., 2005, The Chemistry behind Antioxidant Capacity Assays, $J$. Agric. Food Chem., 53, 18411856.

Khan, K.H, 2009, Roles of Emblica officinalis in Medicine - A Review, Botany Research Internasional ,2, 218-228.

Khurdiya, D.S., \& Jain S.K., 2004, Vitamin $\mathrm{C}$ enrichment of fruit juice based ready-to-serve beverages through blending in Indian gooseberry (Emblica officinalis Gaertn.) juice, Plant Foods Hum. Nutr., 59, 63-66.

Liu, X., Cui, C., Zhao, M., Wang, J., Luo, W., Yang, B., \& Jiang, Y., 2008, Identification of phenolics in the fruit of emblica (Phyllanthus emblica L.) and their antioxidant activities, J. Foods Chem., 109, 909-915.

Liu, X., Zhao, M., Wang, J., Yang, B., \& Jiang, Y., 2008, Antioxidant Activity of Methanolic Extract of Emblica Fruit (Phyllanthus emblica L.) from six regions in China, J. Food Composition and Analysis, 21, 219-228.

Molyneux, P., 2004, The use of the stable free radical diphenylpicrylhydrazyl (DPPH) for estimating antioxidant activity, J. Sci. Technol., 26, 211-219.

Orak, H.H., 2006, Total Antioxidant Activities, Phenolic, Anthocyanins, Polyphenoloxidase Activities In Red Grape Varieties, Electronic Journal of Polish Agricultural University Food Science and Technology, 9,
Prakash, A., Rigelhot, F., \& Miller, E., 2001, Antioxidant Activity, Medallion Laboratories: Analithycal Progress, 19, 1-4.

Ramamoorty, P.K., dan Bono, A., 2007. Antioxidant Activity, Total Phenolic and Flavonoid Content of Morinda citrifolia Fruit Extracts from Various Extraction Processes, Journal of Engineering Science and Technology, 2, 70-80.

Rohman, A., Riyanto, S., dan Utari, D., 2006, Aktivitas Antioksidan, Kandungan Fenolat Total, dan Kandungan Flavonoid Total Ekstrak Etil Asetat Buah Mengkudu serta Fraksi-Fraksinya, Majalah Farmasi Indonesia, 17, 137-138.

SNI 01-2891-1992 : Cara Uji Makanan dan Minuman.

Utami, S., Kasela, S., dan Hanafi, M., 2006, Efek Peredaman Radikal Bebas 1,1-difenil-2-pikrilhidrazil (DPPH) dan Uji Toksisitas Pendahuluan terhadap Larva Udang Artemia salina Leach dari Ekstrak Aseton Daging Buah Sesoot (Garcinia picrorrhiza MIQ), Jurnal Kedokteran Yarsi, 14, 171-176.

Waterhouse, A., 1999, Folin-Ciocalteau Micro Method For Total Phenol In Wine, Department of Viticulture \& Enology University of California, Davis, 152-178.

Zhang, L.Z., Zhao, W.H., Guo, Y.J., Tu, G.Z., Lin, S., dan Xin, L.G., 2003, Studies on Chemical Constituens in Fruits of Tibetian Medicine Phyllanthus emblica, Zhongguo Zhong Yao Za Zhi, 28, 940-943. 